\title{
EESTI TAEVA TÄHENDUSED
}

\author{
Ann Veismann, Anni Jürine, Karl Pajusalu, Renate Pajusalu, \\ Ilona Tragel \\ Tartu Ülikool
}

\begin{abstract}
Ülevaade. Sõna taevas on peetud balti või veel vanemaks indoeuroopa laenuks eesti keeles. Selle laensõnaga väljendati peale taevaruumi ka taevasi ja üleloomulikke-jumalikke nähtusi. Artiklis avame sõna taevas etümoloogilist tausta ning seejärel analüüsime sõna tähendusi ja kasutusmustreid tänapäeva eesti kirjakeeles ja murretes. Näitame, kuidas ruumilises asukoha tähenduses võib sõna taevas olla mõistetud nii objekti, pinna kui ka mahutina. Samuti kõrvutame sõna taevas kasutust sõna jumal kasutustega, osutamaks, et taevas jumala asukohana võimaldab metonüümia KOHT TEGIJA ASEMEL ning sellega sõna taevas mitmekesise kasutuse agendi positsioonis.
\end{abstract}

Märksõnad: eesti kirjakeel, eesti murded, sõna taevas, keeleajalugu, semantika, polüseemia, metonüümia

DOI: https://doi.org/10.12697/jeful.2017.8.1.17

\section{Sissejuhatus}

Koht ja aeg on inimest pidevalt ja vältimatult saatvad kategooriad, seepärast on nii kohta kui ka aega peetud primaarseteks kategooriateks ka keeles: me asume alati kuskil ja tegutseme mingil ajal ning seda aega ja kohta saab keeles väljendada (nt siin ja praegu). Räägitud on ka lokalismist: koht on kui primaarne abivahend, mis aitab mõista suhteid aja valdkonnas ja mitmes muus, keerulisemas valdkonnas (nt emotsioonid, mõtlemine). Seepärast on nii leksikaalsed kui ka grammatilised kohaväljendid väga tihti mitmetähenduslikud. Näiteks saab kohakäänetega väljendada lisaks kohasuhetele ka aega, seisundit, viisi, eesmärki jt suhteid nii eesti keeles (vt Vainik 1995) kui ka paljudes teistes keeltes, sh nt leedu keeles (Klaas 1996). Üks koha mitmetähenduslikkust võimaldav kognitiivne mehhanism on metonüümia ${ }^{1}$, mille järgi koha nimetamisega

1 Tüüpiliselt räägitakse metonüümiast kui osa-terviku asendussuhtest, nt paremkaitse vajab tugevamat jalga (Lakoff ja Johnson 2011: 71). 
on võimalik viidata selle kohaga mingil viisil seotud entiteetidele. Näiteks metonüümia коHT INSTITUTSIOONI ASEMEL laseb meil mõista lauset Toompealt vaadatuna on palju pü̈tud ära teha sotsiaalpoliitika valdkonnas tähenduses 'Riigikogust vaadatuna...'. Koha, asutuse või hoone nimetamine võib seal tegutsevate inimeste või inimrühmade nimetamist asendada süstemaatiliselt (vt Langemets 2010: 178-182). Üks selliseid sõnu eesti keeles, millel on väga selgelt kaks tähendust, kohatähendus ja kohaga seotud tegutseja tähendus, on taevas. Sama kahetähenduslikkus on levinud ka teistes keeltes, kuid on ka keeli, kus eristatakse taevast kui füüsilist nähtust ja taevast kui jumalike olendite elupaika (nt inglise sky ja heaven, ungari ég ja menny). Artikli eesmärk ongi uurida sõna taevas päritolu ja kasutust nii tänapäeva eesti keeles kui ka murretes. Teada on, et varem tähistas taevast (kohana) soome-ugri ühissõna ilm, ning nt selle sõna komi vaste jen tähistab jumala mõistet (SSA 3: 256-257). Ka taeva tänapäevased vasted läti ja leedu keeles tähendavad jumalat.

Järgnevalt anname artikli teises osas ülevaate sellest, mida on teada sõna taevas päritolust. Artikli kolmandas osas analüüsime murdeandmeid, käsitledes eelkõige taevast asukohana, kuid lisades sellele ka näiteid taevast kui jumala asupaigast ja jumala enda omaduste väljendajast. Neljandas osas vaatleme, kuidas kasutatakse tänapäeva eesti keeles sõna taevas asukohale viitavana: mis koht on taevas eestlase keeles. Viiendas osas analüüsime, kuidas taevast on metonüümia abil saanud tegutseja ja kui suurel määral saame rääkida sõnade taevas ja jumal sünonüümiast. Artikli lõpetab sõna taevas tähendusi üldistav kokkuvõte.

\section{Sõna taevas päritolust}

Sõna taevas esineb kõigis läänemeresoome keeltes: soome, isuri, vadja ja karjala keeles kujul taivas, lüüdis ja vepsas taivaz (EES: 507), kuraliivis tōvaz (LELS: 329), Salatsi liivist on üles kirjutatud touvi, tauwis jm (SLW: 199). Sõna on enamasti peetud balti laenuks ( $<*$ deivas). Täiesti üksmeelsed on soome-ugri keelte ajaloo uurijad olnud selles, et tegu on vana indoeuroopa laensõnaga, kuid peale balti päritolu on välja pakutud ka alggermaani laenuallikas $(<*$ teiwas $)$ või seda on arvatud algbaltist veel vanemaks indoiraani laenuks $(<*$ daivas) (Koivulehto 1999: 232, vt Junttila 2015: 105, 108, EES: 507, vt varasemate käsitluste kohta veel SSA 3: 256-257). 
Sõna taevas on levinud soome-ugri keelealal vaid läänemeresoome keeltes, mida arvestades võiks olla balti etümoloogia tõenäosem kui indoiraani oma, paraku on läänemeresoome ja balti keeltes sõnal erinev põhitähendus. Balti keeltes tähendab vastav sõna taeva asemel jumalat: leedu dievas, läti dievs ja preisi deiws, deywis on kõik jumalat tähistavad sõnad. Sõna indoeuroopa algtüve variandid *dei-, *deja-, *dī-, *djāon siiski märkinud (taeva)kuma, hiilgamist, säramist; neist tüvedest on indoeuroopa keeltes tuletatud taevast, jumalat ja päeva tähistavaid sõnu, sh ka ladina deus 'jumal' ja kreeka jumalanimi Zeus; soome-ugri jumala-sõna algupäragi on seostatud sama indoeuroopa algtüve variandiga (vt Koivulehto 1999: 228, Uibo 2014: 190). Arvestades laiemat tähendusvälja ja häälikulisi vasteid (vrd esisilbi vokalismi kohta Junttila 2015: 159), võibki läänemeresoome taevas-sõna laenamise paigutada ka algbaltieelsesse soome-ugri ja indoeuroopa kontaktide perioodi.

Eesti taevas tähendab nii taevast maailmaruumi osana, taevalaotust kui ka taevast jumala asupaigana ja paradiisi sünonüümina. Mitmes maailma keeles on kasutusel nende kahe põhitähenduse eristamiseks eri sõnad, vrd nt inglise sky ja heaven või sugulaskeeltest ungari ég ja menny (viimane religioosses taeva tähenduses). Soome-ugri keeltes on iidne omasõna taeva tähistamiseks olnud $\mathrm{ilm}$, millele on kindlad vasted permi ja obiugri keeltes. Maa ja taeva vastandust kajastab eesti sõna maailm. Huvitav küsimus on, milline oli taeva algne erinevus sõnast ilm siis, kui taevas laenati uue sõnana läänemeresoome algkeelde. Usutavasti oli sõna tugeva afektiivse sisuga ja sellel oli ka religioosne varjund (vt Koivulehto 1999: 228). Vana omasõna ilm hakkas üha rohkem märkima ilmastikku ja seejärel ilmas ehk laiemalt maailmas olevat, lõpuks omandades taevasele lausa vastandlikke tähendusseoseid, vrd eesti keeles tuletatud omadussõnu taevalik ja ilmalik. Sugulaskeeltes on sõna $\mathrm{ilm}$ ja selle tuletised püsinud ka taevase maailma ja selle valitsejate märkijatena, läänemeresoome mütoloogiliste taevasepitsejate Ilmari ja Ilmarise kõrvale asetuvad udmurdi Inmar ning Ilmer; ilma-tüvest pärineb ka sürjakomi jen 'jumal' (SSA 1: 224-225).

Eesti keelega sarnane kasutus on sõnal taevas kõigis läänemeresoome keeltes peale muidu lähedase liivi keele. Liivi keeles tähendab tōvaz 'taevas' ka tormi, rajuilma. Nii on liivikeelse lause sugīz sūr tōvaz mõte 'tõusis suur torm' ja ütlusega tōvaz pū'gõ $b$, mis otsetõlkes oleks 'taevas puhub', väljendatakse tormituule võimutsemist (LELS: 329). Neile liivi tähendusarengutele tuleb otsida eeskujusid balti keelte ajaloost. 


\section{3. taevas kohamurretes}

Taevas on eesti keelealal üldlevinud sõna, mille kohta on rohkesti talletusi kõigist murretest. Järgneva ülevaate aluseks on Eesti Keele Instituudi murdearhiivi sõnavara koondkartoteegi andmestik. Eesti murretes on taevas mõiste, millel on nii ruumi kui ka aine ning isegi taimseid ja isikulisi omadusi. Taeval on servad ja lagi või põhi, isegi väravad, ta võib olla vana, punane või kirju ja minna paksuks, taevas õitseb ja teda saab kutsuda appi.

Taeva kui kolmemõõtmelise ruumi puhul on eesti murretes määratletud nii selle vertikaalset kui horisontaalset mõõdet. Taevast iseloomustab kõigepealt kõrgus (1):

(1) Kas me võime täädä maa sügävust ja taeva kõrkust. (Karksi) 'kas me võime teada maa sügavust ja taeva kõrgust?'.

Horisontaalseid mõõtmeid osutavad taeva piirid, servad, veered $(2-4)$ :

(2) Taeva piir alkab pilve alt vällä näitama (Tõstamaa). 'Taevaäär hakkab pilve alt välja paistma';

(3) Taeva serv lööb lahti (virmaliste kohta, Simuna);

(4) Taivaviir 'taevaäär' sinab (Helme).

Õnneliku inimese kohta öeldi, et ta on taiva veere pääl (Rõuge). Taeva ruumilisust avab peale pilvede ka päikese liikumine. Päiv joba poolen taivan (Nõo) 'päike juba pooles taevas' öeldi keskhommiku kohta, päiv om suuren taivan (Kambja) 'päike on suures taevas' aga lõuna tulekul.

Murdeaines osutab, et taevas ei hakka rahva ettekujutuses siiski otse maa pealt ning see võib olla erineval kõrgusel maast. Pilves ja vihmase ilmaga on taevas madalal (5). Kui vihmapilved kaovad, saab taevas olla kõrgel (6).

(5) Taevas madalas alles, vihm ei ole üle veel, tuleb veel vihma (Anna).

(6) Kui taevas juba nii kõrges on, nüid tuleb teine pää ilus ilm vist (Anna).

Maa ja taeva vahel on vaheruum - taevaalune: kõik taeba alone lage (Martna) 'kogu taevaalune on lage'. Linnud lendavad taeva all: 
taiva alonõ om tsirkõ täüs (Hargla); ka pili 'pilv' oo taeva all (Häädemeeste) ja pikne käristab õkva taivaalust piti (Kambja).

Mõiste taevaalune on võinud saada konkreetsemagi tähenduse. Taevaalusteks on nimetud linde (7), aga ka lennukit (Karksi) ja isegi varanduse kaotanud inimest (8):

(7) Taevaalused pidavad ennast ise toitma (Pöide);

(8) Nüid olen nii puupal'las, taevaalune, põle enam kedagi (Juuru).

Kui maa ja taeva vahel on ruum, siis peaks see jääma taeva põhja alla. Eesti murretest on ülestähendusi taeva põhja ja põranda kohta ometi palju vähem kui taeva lae ja laka kohta. Taeva põhjast räägitakse suure vihmasaju korral (9). Taeva põrandat on mainitud ainult setu aineses (10). Mujal on juttu ikka taevalaest (11):

(9) Ei ole taeval enamb põhja all, kallab iga jumalapäev (Iisaku);

(10) ...lugõva näist mitmõ kimmähe taiva põrmandus, mink takah vahtsõnõ ilm olõvat. (Setu) '(sinist taevalaotust) peavad neist mitmed kindlasti taeva põrandaks, mille taga olevat uus ilm';

(11) Ei taeva laes ole täna ühtki tähte. Välgud käivad taeva lael, müristamist ei kuule (Iisaku).

Taevalagi võib ka ära laguneda (12). Põranda kõrval on taeval lagi ka setus (13). Siin ilmneb ettekujutus taevast, mis algab kusagil pilvedest kõrgemal.

(12) Taeva lagi om ära lagunu, nüid jooseb vett maha (Rannu) 'taevalagi on ära lagunenud, nüüd jookseb vett maha (liigse vihma puhul)';

(13) Pilvõq olõ_i liki taivast, taiva lagi om kavvõbah (Setu) 'pilved ei ole taeva ligidal, taeva lagi on kaugemal'.

Lisaks kahemõõtmelisele taeva laele või põhjale on kirjeldatud taevast ka otse kui platsi (14).

(14) Viimati taeva lat's 'plats' jäi üsna lakes, mõni üksik täheke viil oli (Märjamaa) 'viimati taevaplats jäi üsna lagedaks, mõni üksik täheke veel oli'. 
Taevalae kui kahemõõtmelise pinna kõrval on põhja- ja kirde-eesti murdealal levinud kujutelm taeva lakast (vrd talumaja lakaga): see nü̈d lens 'lendas' kohe taeva lakka (Kuusalu); (pani) nagu taeva lakka (Ambla) 'väga kõrgele'. Iisakust on talletatud isa ja lapse dialoog, kus isa kirjeldab taeva lakka kui panipaika: "Isa, mis-säl taeva lakkas on? Eks vist vihm ole, talvel lumi ja..."

Taevalaotuse mõiste käsitab nii pinna kui ka kolmemõõtmelise ruumi omadusi: taeva laotus on tähtesi täis (Juuru); taeva lautusses on tähed ja päev 'päike' ja kuu. Taevalaotus võib tähendada ka kõike olemasolevat (näide 15, vrd ka järgmises osas kirjakeele näide 71).

(15) Terven taevalaotusen ei ole seast inimest kui sina oled (Helme).

Tähelepanuväärne on sise- ja väliskohakäänete kasutus taevas oleva kirjeldamisel. Lõunaeesti murdealal võivad tähed olla taeva peal:

(16) Sääl taiva pääl kaits ilusat tähte paestava (Nõo) ‘seal taeva peal kaks ilusat tähte paistavad'.

Kesk-Eestis on vikerkaar taeval (Järva-Madise). Sellest erinev on aga igal pool päikese ja kuu asend, need on alati taevas sees, nii ka lõunaeestilises Nõos: päiv om taivan 'päike on taevas'; kui taivan nuur kuи om 'kui taevas noor kuu on'. Lutsi keelesaare arhailise andmestiku järgi elavad inglid küll taevas: pühä hingli umgi taivan 'pühad inglid ongi taevas (st paradiisis)', kuid sinna pääsemiseks peab taivalõ minemä: pühä Piitre lask taivalõ 'püha Peetrus laseb taevasse'; siis taiva väräq om vallalõ 'taeva väravad on lahti'. Siinkohal tuleb siiski silmas pidada, et välis- ja sisekohakäänete kasutus on eesti murretes üldisemalt üsna kõikuv.

Põhjaeesti murdealal on taevaväravate lahtiolekust kõneldud ka suure vihma ajal: nüid oo taeva väratid lahti (Tori) 'nüüd on taevaväravad lahti'. Kui palju sajab, siis tavalisem on küll öelda, et taevaluugid on lahti (17 ja 18).

(17) Kui saul põle lõppu, sis taeva luugid on lahti (Keila).

(18) Nüüd om küll kõik taeva luugid valla (paduvihma puhul, Halliste).

Selget taevast on nähtud võlvina, siis on räägitud taevavõlvist (Häädemeeste). Taevaloogaks on nimetatud aga vikerkaart: vikerkaar joob, see 
oo taeva look (Kihelkonna). Linnuteed on kutsutud taevarajaks (Risti) ja ka taevapeenraks: taevapeenar on üks valge kuma (Lääne-Nigula).

Taeva omaduste kirjeldamisel on esmatähtsad visuaalsed muljed, kuid arvestatud on ka ilmastiku muutumist. Vihma järel selginenud sinist taevast on nimetatud vanaks taevaks nii Lääne-Saaremaal Kihelkonnas kui ka idapiiril Setumaal. Kirjus taevas on veel erineva kujuga pilvi (Häädemeeste). Kui taevas on rünkpilvi, siis taevas õitseb (Karja). Taevas kõrbeb siis, kui taevas on tulekarva punane, see tähendab tormituule tulekut (Pöide). Ida-Eestis võis punane taevas virmaliste korral ennustada sõda (Laiuse). Virmaliste puhul on veel arvatud, et taevas vehkleb (Muhu), taevas eitleb (Käina), taevas lõkleb (Pöide) jms. Mulgimaal Karksis on pilvitamise kohta öeldud, et taevas läits paksus 'taevas läks paksuks', ning ühtlaselt halli pilves ilma kohta, et taevas om üten nahan 'taevas on ühes nahas'.

Sõna taevas kasutatakse sageli kindlates sõnapaarides. Maa ja taevas moodustavad terviku, kui keegi ei tea maast ega taevast (Juuru), ei tea ta millestki. Paaris esinevad samuti ilm ja taevas: küll tormab, kõik ilm ja taevas segi (Kodavere). Tuule ja taeva hooleks jäämine tähendab aga peavarjuta jäämist (näited 19 ja 20, vrd järgmises osas näited 62-64).

(19) Kui tuba ää põles, jäid tuule - taeva ooleks (Juuru).

(20) Jättis mind tuule - taeva kätte 'jättis mind peavarjuta'.

Taevast ja sellest tuletatud sõnu on kõigis murretes kasutatud ka hüüdsõnana, väljendades imestust või kohkumist: oh sa taevas (Juuru), oh sa pühä taevas (Helme); oh sa taevake(ne) (Viru-Nigula, Emmaste, Risti, Põltsamaa jm); oh sa taevake, mis nü̈̈ saab (Kolga-Jaani); oh minu taevane, küll seal oli marju (Muhu); ossa taivakene kuis tuu asi lät's nii halvastõ (Hargla) 'oh sa taevakene, kuidas too asi läks nii halvasti!'.

Mitmes emfaatilises väljendis tähendab taevas pigem jumalat (2123):

(21) Tänu taevale läks kõik hästi (Koeru);

(22) Taevas tule appi (Koeru);

(23) Oh sa taiva halõstus 'oh sa taeva halastus' (Rõngu). 
Jumalat tähendavad otseselt liitsõnad taevaisa $\sim$ taivaesä $\sim$ taevataat jms. Leivu keelesaarelt on aga üles kirjutatud erinev seletus: d'ummal uom puoig õndõ, taivajesa uom d'umala jesa 'jumal on vaid poeg, taevaisa on jumala isa'.

Mitmes eesti murdes tähendab taevaisa $\sim$ taivaesä samal ajal ka äikest, kui müristab, siis öeldakse: taevaisa oo kuri, müristab (Kuusalu), taevaisa tapleb (Tõstamaa, Vändra, Laiuse jm), taevaesä riigleb (Helme) 'taevaisa riidleb, s.t müristab', taevaesä tõreleb v. kärgib (Rannu). Taevas on taevaste jõudude elupaik, need jõud võivad olla hirmuäratavad, kuid taeva omadused on ikkagi ihaldusväärsed. Omadussõna taevalik tähendab kõikjal väga head, jumalikku, imeilusat jms, kõigil murdealadel on tuntud taevalik rõõm, taevalik elu, taevalik õnnistus jms.

\section{4. taevas kui asukoht ja objekt tänapäeva kirjakeeles}

Järgnevalt analüüsime sõna taevas kasutust eesti kirjakeeles objektile ja asukohale viitavana (s.t taevas kui taevalaotus ja kui maailmaruumi osa). Aluseks on võetud eesti kirjakeele korpuse tasakaalus korpus (150 miljonit sõna) ja internetikeele korpus etTenTen (270 miljonit sõna), näiteid on võrreldud ka andmetega Eesti murrete korpusest. Selgitame, mis koht tänapäeva eesti keeles taevas on, kes ja kuidas sinna pääsevad või seal asuvad ning millised on selle paiga omadused. "Eesti kirjakeele seletussõnaraamatu" järgi saab taevast mõista kaheti: see on nähtav taevaruumi osa ja jumalate asupaik ning paradiis (EKSS, vt ka A. Õim 2004: 131-133). Mõlemas tähenduses on see koht inimese maailmas, esimeses tähenduses hõlmab taevas väga laialt mõistetud asukohta, kus võime näha nii õhupalle, lennukeid, pilvi kui ka taevakehi, Päikest ja Kuud; teises mõttes on see (otsese füüsilise asukohata) koht, kus asub/vad Jumal või jumalad.

Asukohana saab taevast mõista objekti, pinna või mahutina sõltuvalt sellest, mitmele ruumimõõtmele väljendis tähelepanu pööratakse.

Objektina mõistetud taeval on palju eseme tunnuseid: ta võib olla mingit värvi, teda saab näha ja vaadata (24-25).

(24) Tavapäraselt tähelepanelikud ja eriti lühinägevusega inimesed näevad silmade ees, kui unistavalt vaadata halli taevast, ujuvaid rõngakesi, täppe, niidikesi.

(25) Juuresolevalt pildilt on näha väike osa taevast, mida Herschel on vaadelnud. 
Taevas võib olla objekt, mille abil määratakse liikumise (või vaatamise) suund. Kui prepositsiooni vastu esmane ruumiline tähendus on (EKSS järgi) '(hooga) millegagi vahetusse kokkupuutesse; vahetus kokkupuutes; pihta, külge', siis taeva puhul jääb kuulaja/kõneleja fantaasia otsustada, kuivõrd on tegemist vahetu kokkupuutega (näited 26 ja 27). Vaatamise korral saab taevas märkida vaid suunda (näited 28 ja 29), samuti vaadatakse vastu valgust ja päikest, aga palju rohkem neid entiteete polegi, vastu mida vaadata saaks.

(26) Kui Kiku kodulinna (...) jõuab, siis ilutulestik lendab vastu taevast ja linnaametnikud peavad paatoslikke kõnesid ja koorid laulavad ja kooliõpilased toovad lilli.

(27) Esimese MIG-i piloot tulistab raketi välja, käib kõmakas ja vastu taevast lendab hunnik musta sodi.

(28) Sügisõhtuti on vastu taevast vaadates näha, kuidas nad lendavad.

(29) Sääl viskas nüüd kunstnik niidikera vastu taevast ülesse (...)

Enamik korpuse näidetest kaassõnafraasiga vastu taevast pole siiski mitte ruumisuunalises, vaid piltlikus tähenduses 'nurjuma, luhta minema'. Kui tavapäraselt väljendab ülesliikumise suund kooskõlas metafooridega ÜLEVAL ON HEA, ÜLEVAL ON ROHKEM positiivset või arvulise suurenemise muutust (asjad lähevad ülesmäge, hinnad tõusevad, näide 30), siis lendas vastu taevast tähendust ei saa selgitada orientatsioonimetafoori HEA ON ÜLEVAL abil.

(30) Ning seekord käib välja järgmise ettevõtte aktsia, mis kohe peaks üles lendama ja ehk isegi lendab.

Kuid väitmaks, et eesti keel kasutab orientatsioonimetafoori HALB ON ÜLEVAL, jääb ühest fraseoloogilisest väljendist väheks, metafoori esinemine peaks olema süstemaatiline - vastava metafoori alusel peaks saama kasutada ka teisi sõnu, nt lisaks lendama verbile peaks olema esindatud ka muud liikumisverbid ja/või lisaks vastu prepositsioonile ka muud ruumisuunda väljendavad pre- ja postpositsioonid või adverbid (poole, üles). Võib oletada, et negatiivne tähendus tuleb vastu taevast väljendites prepositsiooni vastu põhitähendusest 'vahetusse kokkupuutesse, pihta' - millegi pihta lendamise tagajärjed ei ole füüsilises kogemuses positiivsed. Lisaks mõjutab negatiivset tõlgendust ilmselt 
ka kattuv tähenduspiirkond plahvatuse ja lõhkemise väljenditega, vrd nt õhku lendama.

Taevas kui suunanäitaja kajastub ka kaassõnafraasis taeva poole, mis esineb üsna neutraalse sünonüümina väljendile ülespoole (näited 31 ja 32), kuid võib olla seotud ka üldise uskumusega taevast kui jumala asupaigast (näide 33).

(31) Lama põrandal maas, käed taeva poole.

(32) Vihmaussid nahistavad veel murukamara sees, mutid kergitavad neid mullakuhjaga taeva poole.

(33) Sõbranna aga tõstab silmad taeva poole ja tänab jumalat õiglase otsuse puhul.

Kaassõnafraasides mõistetakse taevast veel objekti või pinnana väljendites keset taevast, kesk taevast ja taeva keskel. Objektid, mis paiknevad keset taevast, on enamasti taevakehad (34).

(34) Toimetuselt: Päike ja Kuu ei ole horisondil suuremad kui keset taevast.

Folklooris ja murretes võib taevas olla ka objekt või laotus, mille külge kas taevakehad või taevas asuvad objektid on kinnitunud (näited 35 ja 36) või mida tükeldada õnnestub (37).

(35) Mälestuseks jäänud sest endisest õnneajast nüüd tähed igaveste taeva külge.

(36) Kui õhtu valged pilved taeva küljes on, siis saab järgmisel päeval ilus ilm, kui aga mustad pilved, siis vihmane ilm.

(37) Kord juhtus ühel rätsepal püksilappi tarvis olema ja ta lõikas kogemata taeva küljest tüki lahti.

Mitu kaassõnafraasi toob esile taeva kui pinna, mida mööda saab liikuda (üle taeva, mööda taevast, piki taevast). Peamised mööda või piki taevast liikujad on pilved (näited 38 ja 39).

(38) Mööda taevast kihutavad pilved - selline vaade mõjub võluvalt.

(39) Ninast nuusatud pilved venivad piki taevast ning nõrguvad horisondil tõmmatud piiri taha. 
Üle taeva liikujate hulk on mitmekesisem, võib öelda, et kui mööda taevast liigutakse pigem maa atmosfääris (nt pilved ja lennukid), siis üle taeva liikuvad objektid võivad paikneda ka maa atmosfäärist väljaspool (näited $40 \mathrm{ja} 41$ ).

(40) Jupiter tõuseb täna õhtul kl 19.30 idast ja rändab (peaaegu) täiskuu järel üle taeva.

(41) Mida lagedam vaateväli, seda parem, sest perseiidid lendavad pika jutiga üle taeva.

Samas võib üle taeva tähendada ka palju maalähedasemat trajektoori, nagu näidetes 42 ja 43 :

(42) Rasked pilved aga aina sõudsid üle taeva, mattes terved mäetipud paksu vati sisse, nii et raske oli näha ja kummaline oli hingata;

(43) Üks part paneb laperdades madalalt üle taeva.

Kaassõnal üle on liikumistrajektoori tähenduse kõrval ka katmise, laialivalgumise tähendus (vt Veismann 2009) ning see tuleb esile ka üle taeva fraasides (äiksepilv laotab end üle taeva), näited 44 ja 45.

(44) Pimedus tatsub noil päevil juba üsna vara üle taeva ja pilveräbalad varjavad iga vähegi vallatuma päikesekiire, mis veel suvest viinakuusse lipsata on julgenud.

(45) Ma valetasin, tumedad pilved laotusid üle taeva.

Teekonnaga on seotud ka läbi taeva, kujutades taevast ruumina, millest läbi saab liikuda (näited 46 ja 47). Nii läbi kui ka kaudu toovad lisaks teekonnale esile ka tee paiknemise pigem kolmemõõtmelises ruumis (mahutis) kui pinnal (nagu mööda ja üle).

(46) Lõppegu lend läbi taeva, tiibade kokkupanekuga pesa kohal.

(47) 20. novembri varahommikul nähti Kanadas Saskatchewani ja Alberta provintsides läbi taeva sööstmas võimsat tulekera.

Taeva kaudu näitab, et teekond on seotud vahendatuse, võimaldamisega. Sihtpunkti kohalejõudmine on võimalik ainult mingit teed pidi, mingi koha kaudu liikudes. Vahendatus võib olla otsesem ('taevas 
satelliidi asupaigana', näide 48) või kaudsem ('taeva abil; taevas üleloomulike jõudude asupaigana', näide 49).

(48) Liibüas kehtis veel kevadel täielik infosulg, vaid taeva kaudu jõudis inimesteni Katarist lähtuv al-Jazeera telepilt.

(49) Justkui tõesti oleks Reijo kaugelt Mikkelist mulle taeva kaudu roose saatnud ...

Mahutina mõistestatud taevas võib olla kas avatud ruum, millel selgeid piire ei ole või vähemalt ei ole neid aktualiseeritud (50), või suletud ruum, millel võivad olla luugid või väravad (51). Viimane tähendus selgub eriti hästi, kui võrrelda sõna taevas sõnaga õhk, mis on alati avatud ruum (A. Õim 2004: 132).

(50) Kuu oli vahetanud taevas asendit, valgustades jõe asemel hoopis kirikut.

(51) Aga nüüd olid taevaluugid päris valla ja vihma hakkas kui oavarrest kallama.

Kaassõnafraasid taeva sees ja harva ka taeva seest toovad esile taeva kui ruumi, milles võivad asuda taevased isikud või taevakehad (näited 52-54).

(52) Kui meie avatud süda koos laulikuga heliseb: "Helde Isa taeva sees, heida armu minu pääl”.

(53) Seal üleval, helesinise taeva sees, oodatakse mind, seal on soe ja pehme, seal ei ole valus.

(54) Halvavalt heledaid tähti kobrutava taeva seest plinkimas.

Erinevalt postpositsioonidest sees ja seest, mis viitavad ruumilisele mahutile, loob kaassõna sisse koos taevaga folkloorsetes tekstides kujutluse pinnast, mille külge (sisse) saab teisi objekte kinnitada (55) või mille sisse auke tehes hakkab paistma taevast kui katvast/varjavast objektist teisel pool asuvat valgust (56).

(55) Tähed on vanapaganast taeva sisse löödud naela pead.

(56) Ja üks sepp võtnud pihid, teinud nendega taeva sisse augu, tema naene teinud veel suurema augu, sest on päev ja kuu ja tähed saanud. 
Sama kontseptsiooni võime oletada ka prepositsioonifraasi sealpool taevast aluseks olevat (57).

(57) Taevas, põrgu ja puhastustuli asuvad kuskil kaugel sealpool taevast või maa all.

Kui taevas on kõneleja jaoks kattev objekt (vrd ka taeva sünonüümid taevalaotus, taevavõlv, taevakumm, taevatelk, taevalagi, taevaalune, taevakuppel, taevalapp (Sünonüümisõnastik), siis selle alusel saab rääkida taeva all olemisest, nt kaassõnafraaside taeva alla, taeva all ja taeva alt abil. Seejuures võib piirkond, millele saab viidata kui taeva all olevale, olla nii maa peal (näited 58 ja 59) kui ka õhus (näited 60 ja 61).

(58) Hommikul aknast välja piiludes ei tundunud küll eriti ahvatlev soojast toast halli vihmase taeva alla minna, aga nagu öeldud: ei ole halba ilma, on vaid vale riietus.

(59) Kohalik äike võib tekitada olukordi, kus ühe küla kohal käib tõeline paugutamine, välgud ja sadu, aga naaberküla inimesed vaatavad seda pealt selge taeva alt.

(60) Lendasin õhupalliga taeva all.

(61) Taeva alt kostus sookurgede kurbi lahkumishäli.

Seejuures võivad olla täpsustatud katva taeva omadused (kõrge, madal, hämar, sünkmust, õnnis, sünge, sügisene, lahtine, paljas, tinaraske, hall, sinine, pilvine, pilvitu, tähine). Log-tõepära statistiku järgi kollokeeruvad sõnaga taevas kõige sagedamini adjektiivid sinine, lage, pilvitu, selge, hall (tasakaalus korpuse andmed) ${ }^{2}$. Mainitud võib olla ka taeva(laotuse) "omaja" ehk see koht, mida taevas katab (Pariisi taeva all).

Omaette huvitav väljend on lage taevas ja eriti lageda taeva all, lageda taeva alla. Kui lage tähendab tavaliselt 'tõketeta, tühi, paljas' (EKSS), siis lageda taeva puhul ei ole tühi ja paljas taevas ise, vaid inimese (või muu kõneks oleva entiteedi) ja taeva vahele ei jää midagi, mis seda varjaks (62). Samas tähenduses, kuid oluliselt harvem, esinevad ka palja taeva all ja lahtise taeva all (näited 63 ja 64).

2 http://tinyurl.com/hglr7la (vaadatud 27.12.2016) 
(62) Kogu jama ongi ju selles, et paljud kardavad aastaks lageda taeva alla jääda!

(63) Ta sai alles hiljem aru, et meie külmal maal sa ei saa elada palja taeva all või käia ringi ilma jalanõudeta talvel.

(64) Turg oli küll lahtise taeva all, nii et ma ei tea, kas see nüüd sellise lumega ka toimub.

Kaassõnad vahele, vahel, vahelt on taevaga seotud eelkõige väljendites maa ja taeva vahel, maa ja taeva vahele, maa ja taeva vahelt, millega viidatakse kas kõrgemale kohale maapinnal (65), maapinnast kõrgemal, kuid füüsilise objekti toetusega (näited 66 ja 67), või ilma otsese toetuseta õhus hõljumisele (näited 68 ja 69). Fraaside maa ja taeva vahel/vahele kasutused kinnitavad Asta Õimu väidet, et kuigi taevas ja õhk võivad olla ka sünonüümid, kajastub nende sõnade kasutuses pigem kujutlus, et maa ja taevas otseselt kokku ei puutu, sest nende vahele jääb õhk (Õim 2004: 131).

(65) Meelelahutust pakkusid lehmad ja lambad, kes täiesti absurdsetes kohtades rõõmsalt maa ja taeva vahel kiviklibu hulgast välja turritavaid heinatuuste näsisid.

(66) Arboristitöö on huvitav ning selles on seikluse maiku - töö toimub ju maa ja taeva vahel!

(67) Mida korstnapühkija teeb seal kõrgel maa ja taeva vahel?

(68) Lindaur lähenes helitutel sammudel, ta jalatallad justkui ei puudutanudki põrandat ning ta liikumine oli kui hõljumine maa ja taeva vahel.

(69) Seal üleval, maa ja taeva vahel, on KÕIK teistmoodi ja samas nii kodune.

Väljend maa ja taeva vahel on sünonüümne sõnaga õhus, ning seda ka metafoorsemates väljendites, kus maa ja taeva vahel olek võib viidata abstraktsemalt tasakaalu puudumisele või ebakindlusele (70), mille aluseks on metafoor KINDLUSTUNNE ON FÜÜSILINE TOETUS ning mis viitab kehalisele kogemusele vastavast olukorrast (vrd ka väljendeid on kahe jalaga maa peal; jääb õhku rippuma). 
(70) 300 vene keeles psühholoogiat õppivat tudengit võivad sügisest jääda maa ja taeva vahele, sest nende õppekava ei vasta nõuetele ja võidakse seetõttu sulgeda, edasi pole neil aga kusagil õppida.

Väljendil maa ja taeva vahel on ka laiem, üleüldse eksistentsile viitav tähendus (71). Vastavate $\tilde{o} h u$-väljendite (nt õhus on kevadet) aluseks peab A. Õim mahuti-metafoori, mille järgi “õhk on ruum, mis on täidetud inimest alaliselt ja kõikjal ümbritseva ainega" (Õim 2004: 129-130). Nii võib ka öelda, et väljend maa ja taeva vahel viitab ruumile, mis on täidetud kõige eksisteerivaga (vrd näide 15 murretest, taevalaotus). Võrdluseks saab tuua ka sõna $\mathrm{ilm}$, mis varem eesti keeles taevast tähistas ning on säilinud taeva või jumala tähenduses mõnedes sugulaskeeltes, nagu saami ja permi keeled (Uibo 2014: 188-189). Liitsõna $m a a+i l m$ on läinud kasutusele samuti kogu ümbritsevat eksisteerivat tähistavana.

(71) Maa ja taeva vahel on paljugi veidrat. Vrd Maailmas on paljugi veidrat.

Samas võib taevas olla ka ise osadeks lahutatav, nii et selle osade vahelt või vahel paistab midagi (näited 72 ja 73).

(72) Mõtlesin siis positiivselt, et oi, sellise tumeda taeva vahelt on isegi natuke heledat taevast näha.

(73) Aga hommikuti oli taeva vahel madalaid inetuid pilveräbalaid ja [...]

Kuigi taeva asukoht inimese ja maa suhtes on kindlalt ülal ja seda kasutatakse ülespoole osutamiseks (taeva poole 'üles', vt ka A. Õimu näiteid üles, õhku ja taevasse sünonüümiast (Õim 2004)), siis taeva enda asukoht muude objektide, eriti taevasse või kõrgematesse sfääridesse kuuluvate objektide (tähed, päike, pilved) suhtes pole alati sugugi nii selge. Näiteks võivad pilved, päike jm olla väljendatud taevast kõrgemal paiknevatena kaassõnadega kohale ja kohal (näited 74-76).

(74) Tumedad pilved tõusid taeva kohale, aga lapsed ajasid ikka naerdes palli taga.

(75) Päike troonis Põlvamaal taeva kohal, kui Võõpsus libises üle finišijoone võitjapaat: meresüst pärnakate Uko Kõrge ja Kaubi Türnpuuga.

(76) Toksilised väävliaurud kerkisid kõrgeist korstnaist ning hõõgusid kollakalt tumeda taeva kohal. 
Võimalik, et see annab tunnistust varasemast ettekujutusest, mille näiteid leiame murdekorpusest ja folkloorist kaassõnafraasi taeva peal näol (näited 77-80; vt ka eelmises osas murdenäide 16). Samas ei pruugi ei taeva peal ega taeva kohal märkida mitte vaadeldava objekti ja taeva absoluutset asetust teineteise suhtes (nii et kohal või peal peaks märkima taevast vertikaalsuunas kõrgemal asumist), vaid pigem samapaiksust (koht: koha tähenduses ning nii nagu nt lausetes kärbes kõnnib seina peal; koputi on ukse peal). Nii kohal, kohale kui ka peal, peale annavad neis näidetes suuna, kuhu kuulaja peaks objekti otsides pilgu pöörama.

(77) $\mathrm{ja}=$ see tuli+änd oli koa 'jälle sedasi ond (.) maa $=$ (olin) (.) kass $=$ se $=$ nd tuli+ännad a maa ole näind küll (.) õ õ 'taeva $=$ pial 'õhta pimidas ’lindäväd tule+jugad (...) (Lää)

(78) vat kui `öhta sedasi punab `taeva peal kas siis pidi kaa `tormi tulema vöi (...) (Saarte)

(79) Arvati vanasti, et pilved käivad taeva peal, mitte all.

(80) Korra olid mustad pilved taeva peal nähtavale tõusnud, kiirelt kõik Vaela küla kohta sõudnud ja kui toobrist oma vett küla peale kallanud, nii et väha aja järele küla asemele järv oli ilmunud.

Kokkuvõtteks võib öelda, et ettekujutus taevast kui kohast võib olla üsna mitmekesine ning seda peegeldavad näited nii eesti kohamurretest kui ka tänapäeva kirjakeelest. Järgnevalt vaatleme, kuidas kirjakeele näidetes avaldub kujutlus taevast kui tegutsejast.

\section{5. taevas kui tegutseja tänapäeva kirjakeeles}

Tänapäeva kirjakeeles on taevas samuti ühelt poolt Jumala asukoht, teiselt poolt aga sünonüümne Jumala endaga (näited $81-84$, vrd murdenäited 21-23). Eriti hõlpsasti on jumal ja taevas vastastikku asendatavad hüüdlausetes tule taevas/jumal appi! taevas/jumal hoidku! taevakene/ jumalukene! tänu taevale/jumalale jms. Samuti esineb palju paralleelsust väljendites jumal/taevas teab tähenduses 'keegi ei tea' (Jürine jt 2016: 16, Kehayov 2009). Kuigi süntaktiline paralleelsus on ilmselgelt olemas ka paljudes muudes väljendites (nt taeva/jumala õnnistus, taeva/jumala kingitus), ei pruugi see siiski olla absoluutne, sest keele kasutajate jaoks ei pruugi need variandid alati sama tähendada. 
(81) Tänu taevale ja riigiisadele on haigekassa krooniliste haiguste ravi seni enda peale võtnud.

(82) Igasugused esiisade vaimud ja haldjad ja taevas teab kes jahuvad ikka mingitest elumõtetest ja ettemääratusest ja saatuse käikudest.

(83) Kartulgi põldudel on nii kidur, nagu oleks ta taeva õnnistusest ilma jäänud.

(84) Lausa taeva kingitus, muud ei mõista ütelda!

Sama sõna erinevad käändevormid on tähenduselt tihti spetsiifilisemad kui lekseem tervikuna (nähtust võiks vaadelda leksikaliseerumisprotsessina, vt ülevaadet nt Velsker 2010). Nii on komitatiivne taevaga kasutusel eelkõige ilma kirjeldamise puhul tingimusmääruse või atribuudina (näited 85 ja 86) ja paralleelsus vormiga jumalaga on kui mitte võimatu, siis ebatõenäoline.

(85) See tekib uduse ilma korral, kui päike paistab läbi udu nii, et tekivad täisvarjud ehk udu on tavaliselt selge taevaga.

(86) Kevadtalvine tähistaevaga öö edenes ning Aliide vaevles üha suurenevate valude käes.

Teine näide vormi tähenduse spetsiifilisusest võiks olla taevani. Kui jumala esineb väga sageli intensiivistajana (jumala suur, jumala õnn, jumala kangestusin, jumalast äge vt Jürine jt 2016), siis sõnal taevas on intensiivsuse tähendus ainult terminatiivi vormis eelkõige koos verbidega kiitma, ülistama ja kis(end)ama (87 ja 88), aga ka koos mõnede omadussõnadega (taevani õnnelik, vt A. Õim 2004: 132). Samas ei ole selles kontekstis võimalik kasutada jumalani, sest jumala intensiivistav tähendus esineb genitiivis või elatiivis. Leidub kontekste, kus vorm taevani võib olla mõistetud nii otseses tähenduses (visuaalselt taevasse ulatuv) kui ka metafoorse intensiivistajana (89).

(87) Nende valikut pole põhjust hukka mõista ega taevani ülistada.

(88) / .../aga kui nii, kui taevani kisendava ebaõigluse eesmärk on saavutada senisest suurem Tema poole hüüdmine, siis on kurjategija vastupidiselt kohtu eeldusele hoopis heateo tööriist. 
(89) Sealsamas vedas kõrb mära nurga tagant välja ree taevani kõrguva vitsakoormaga, see tõmmati lumele maha ja pikk pink, köied küljes lohisemas, tassiti sinna kõrvale.

Nagu eespool kirjeldatud (vt näited 21-23 ja 81-84), esineb sõna taevas kasutustes personifikatsioone. Sellistes näidetes esineb taevas AGENDI rollis. Et leida vastus küsimusele, mis tegevusi taevas sellistes kasutustes täpsemalt "teeb", tegime internetikeele korpuses etTenTen (270 miljonit sõna) päringu kõikide lausete kohta, kus lemma taevas esineb ainsuse nimetavas käändes, millele järgneb verb, mis on isikulises tegumoes, kindlas kõneviisis, ainsuse kolmandas pöördes ja jaatavas kõnes. Verb olema välistati päringus, kuna selle kaasamine tähendaks väga suurt hulka materjali, mis nõuaks teistsugust analüüsi, mis ei anna vastuseid meid käesolevas artiklis huvitavatele küsimustele.

Päringu tulemusel saime 1050 lauset. Need laused vaadati ükshaaval läbi ning valimist kustutati kõik näited, kus taevas ei olnud grammatiline subjekt, misjärel jäi lõplikuks analüüsiks 403 näidet. Siin analüüsitavate andmete hulgast välja arvatud näidete suur hulk tuleneb eelkõige sõne taevas käändevormide vormihomograafiast. Näiteks ei ole automaatse morfoloogilise analüüsi käigus alati õigesti määratud, kas tegemist on nimetava (90) või seesütleva (91) vormiga. Esimesel juhul viidatakse taevale kui personifitseeritud entiteedile, teisel juhul paigas asumisele. Teatud juhtudel on aga võimalikud ka mõlemad tõlgendused (92).

(90) Siis tuleb vajadus lähemale - järelikult annab taevas ka vahendid.

(91) See igavene vaim elab, pannes oma maised ihupaelad hauda varjule, taevas suure jumala juures.

(92) Tänu Kristusele võivad inimesed nüüd oma kuulekuse kaudu näidata, et taevas võib neid usaldada - nad ei hakka kord igavikus Jumalale vastu. MS48, 1893

\subsection{Sõnaga taevas sagedasti koos esinevad verbid}

Järgnevalt esitame sõna taevas sagedamad kollokaatverbid nii absoluutse sageduse alusel (vt tabel 1) kui ka sõnadevahelise seose tugevuse alusel (arvutatud log-tõepära meetodil (vt tabel 2) (log-tõepära statistiku kohta vt Evert 2005). 
Tabel 1. Sõna taevas 10 sagedasemat kollokaatverbi absoluutse sageduse alusel

\begin{tabular}{|llc|}
\hline \# & verbi lemma & $\begin{array}{c}\text { verbi abs } \\
\text { sagedus }\end{array}$ \\
\hline 1 & selginema & 19 \\
2 & võima & 18 \\
3 & teadma & 16 \\
4 & minema & 14 \\
5 & tõmbuma & 13 \\
6 & tulema & 13 \\
7 & andma & 13 \\
8 & hakkama & 13 \\
9 & paistma & 12 \\
10 & jääma & 11 \\
11 & saama & 10 \\
12 & kukkuma & 9 \\
13 & muutuma & 8 \\
14 & kattuma & 7 \\
15 & avanema & 7 \\
\hline
\end{tabular}

Tabel 2. Sõna taevas 10 sagedasemat kollokaatverbi sõnadevahelise seose tugevuse alusel

\begin{tabular}{|llc|}
\hline \# & verbi lemma & $\begin{array}{c}\text { log-tõepära } \\
\text { skoor }\end{array}$ \\
\hline 1 & selginema & 204 \\
2 & tõmbuma & 80 \\
3 & võima & 62 \\
4 & saama & 61 \\
5 & tulema & 55 \\
6 & punama & 47 \\
7 & minema & 44 \\
8 & andma & 41 \\
9 & kattuma & 38 \\
10 & teadma & 38 \\
11 & hakkama & 36 \\
12 & jääma & 35 \\
13 & pidama & 27 \\
14 & tumenema & 27 \\
15 & särama & 25 \\
\hline
\end{tabular}

Tabelitest 1 ja 2 on näha, et kahel meetodil leitud sagedasemad kollokaadid langevad suures osas kokku (varjutatud lahtrid). Analüüs näitab, et kõige sagedamini taevas selgineb, võib, teab, läheb, tõmbub, tuleb, annab, hakkab, jääb, saab ja kattub. Suure koosesinemise sageduse (ja väiksema üldsageduse tõttu) võib taeva tugevamateks kollokaatideks lugeda verbe punama, pidama, tumenema ja särama. Verbide muиtuma ja minema sagedus osutab taeva muutumisega seotud situatsiooni olulisusele igapäevaelus.

Sagedate kollokaatide hulgas on ootuspäraselt palju tuumverbe (vt Tragel 2003): tulema (93), saama (94), andma (95), pidama (96), võima (97), minema (98) ja jääma (99). Kõik näidetes 93-97 loetletud tuumverbid on esindatud ka jumala sagedasemate kollokaatide seas (vt Jürine jt 2016: 13, 18). Lausetes, kus taevas on määratletav aktiivse tegijana, võib taevas viidatagi jumalale või jumala asupaigale.

(93) Uskliku inimese jaoks tuleb taevas juba selles elus alla ja annab eelmaitse sellest, mis tuleb. 


\section{Ann Veismann, Anni Jürine jt}

(94) Juba siin maa peal peame algama elama Kristuse elu, ja siis saab taevas nii sulle kui neile, kes sinuga kokku puutuvad.

(95) Annab meil taevas kodusse jõuda, mõtetes meiega käite.

(96) miks peab taevas alati ansipile appi tulema

(97) Selle lepingu alusel kuuluvad neile kõik õnnistused, mida taevas võib anda nii selles kui igaveses elus.

(98) See juhtub siis, kui teiste universumite kiirgus jõuab lõpuks meieni ja taevas läheb valgeks!

(99) Kõige selgemaks jääb taevas põhjarannikul ja Kirde-Eestis.

Jumala ja taeva tegudel on teisigi paralleele. Näiteks kuulub mõlema sagedamate kollokaatide hulka verb teadma (Jürine jt 2016: 16). Nii jumal teab kui taevas teab väljendavad tähendust 'meie [surelikud] ei tea' (vt näide 100).

(100) Mis Toobali-Laasiga edasi saab, teab vist vaid taevas.

Taevas ei pruugi lauses olla aga ainult AGENDI rollis. See võib olla ka PATSIENT või KOGEJA, kuid olla siiski lauses grammatiline subjekt. Selliseid kasutusi illustreerivad näited, kus taevas viitab maailmaruumi osale, mis ei ole aktiivne tegija, vaid millega toimuvad teatud protsessid, nt selginemine (101), tumenemine ja omandamine (102), punamine (103), kattumine (104) ning juba ülal mainitud muutumine (105) ja minemine.

(101) Juhul kui taevas selgineb, langeb Ida-Eestis alla -15 kraadi.

(102) Kell kaheksa õhtul taevas tumeneb ja omandab eriliselt särava sinise tooni; siis, väga järsku, saabub öö.

(103) Aga ta kostis ning ütles neile: “Õhtu tulles te ütlete: head ilma tuleb, sest taevas punab."

(104) Hiljem kattub taevas pilvedega ja tuleb esimest lund, mis järgmisel päeval küll jälle kaob.

(105) Et kas see väikese tähega taevas muutub siis kohe mõistuspäraseks ja välistab sinu jaoks igasuguse ahhetuse, $\mathrm{mh}$ ? 
Kõigis neis näidetes väljendab verb muutust ning kui verb ise muutuse iseloomu või tulemust ei täpsusta, teeb seda mingi teine, täpsustav lauseliige. Nii võib taevas muutuda mõistuspäraseks (105) ja omandada särava sinise tooni (102).

\subsection{Sõnaga taevas vähem sagedasti koos esinevad verbid}

Taeva kollokaatverbide seas pakuvad huvi ka lemmad, mis statistiliselt kuigi sagedased ei ole. Näiteks kuulub vähesagedaste verbide hulka aitama, mis esines materjalis vaid kolm korda (106). Kuigi taevas on jumala tähenduses tihti abistaja rollis, seostub see tähendus rohkem ühendverbiga appi tulema. Tavaliselt esineb appi tulema hüüatuses tule taevas appi! ning sel juhul on taeva-sõnaga seostuvaks verbiks hoopis tulema $^{3}$.

(106) Kui teaks, et taevas aitab, karjuks: “Tule taevas appi!”.

Vähesagedaste verbide hulka kuulub ka tuumverbe. Näiteks ei kuulu taeva sagedamate kollokaatide hulka tegema, mis esines meie andmestikus vaid ühel korral (107). Samas kuulub tegema-verb jumala sagedasemate kollokaatide hulka (Jürine jt 2016: 13, 18). Taeva ja tegemaverbi koosesinemise ainsast näitest näib, et tegema-verb ei seostu taeva kui jumala (või jumala asupaigaga), vaid just taeva kui maailmaruumi osaga. Seetõttu on üsna ootuspärane, et agentiivsele tegevusele viitavat verbi nagu tegema esineb materjalis vähe.

(107) Samas kogumikus väidab Viivi Luik, et maastiku teeb maastikuks taevas, valgus ja vari.

Vaid üks-kaks korda esinenud verbide hulgas leiame ka näiteid, mis annavad selget tunnistust kõnelejate loomingulisest keelekasutusest, näiteks verbide vürtsitama, vedama, suhtlema, kogema ja tühjenema kasutus taeva tegevuse märkimiseks võib esmapilgul üsna üllatav tunduda. Vaatame esinenud näiteid (108-112):

(108) Pilvine taevas vürtsitab pilti oma dramaatilisusega.

3 Meie andmestikust jäid sellised näited otsinguparameetritest tulenevalt välja, kuna tegemist on tulema-verbi imperatiivse vormiga. 
(109) Kogu taevas suhtleb aktiivselt universumi kõigi osadega erinevaid kanaleid pidi ning Püha ise kummardub tegelikult alla oma troonilt, kuulates iga kuuldavale toodud heli, jälgides kõigi maiste jõudude liikumisi.

(110) Kui me ei tule koju, kogeb taevas kaotust.

(111) Nõnda siis veab taevas end oma värvidega päikesele vaevaliselt järele.

(112) Taevas tühjeneb inglihulkadest.

Nagu muutumist väljendavate verbide puhul, nii ka siin leiame sellist tüüpi kasutuse põhjendatuse enamasti verbiga seotud teistest elementidest. Näiteks saab taevas vürtsitada pilti - see annab vastuvõtjale signaali, et tähendust tuleb otsida piltliku keelekasutuse vallast. Koos verbiga vedama esineb refleksiivpronoomen ise: taevas veab end. Niisiis on siingi tegemist isikuks muutunud taevaga.

\section{Kokkuvõte}

Artiklis oli vaatluse all sõna taevas päritolu ja semantika. Esmalt oli arutluse all sõna taevas päritolu. Kui enamasti arvatakse, et see on balti laen, siis tõenäosena on välja toodud veelgi vanemat indoiraani päritolu. Sõna olemasolu ainult läänemeresoome keeltes näib toetavat balti laenu, kuid balti keeltes ei tähenda vastav sõna mitte taevast, vaid jumalat. Seevastu indoeuroopa algtüve variandid on märkinud (taeva) kuma ning tuletised ka jumalat ja päeva.

Tänapäeva eesti keeles on sõnal taevas kaks peamist tähendust: ruumiline asukohatähendus ja (mõtteline) jumala(te) asupaiga tähendus. Ruumilises asukohatähenduses võib sõna taevas esineda objektina, pinnana või mahutina. Objektina võivad taeval olla mitu eseme omadust (värv, vaadeldavus, osadeks jaotatavus, piiritletus), selle järgi saab määrata vaatamise suunda. Pinnana on taeval esil kaks mõõdet, taevas on kattev, taevased objektid saavad paikneda selle küljes või liikuda mööda selle pinda (üle, mööda, piki). Mahutina võib taevas olla kas avatud ruum, millel selgeid piire ei ole, või suletud ruum, millel võivad olla luugid või väravad. Kuna taeva ulatus on suur ja piiritlemine keeruline, saab kõnelda objektidest nii taeva all kui ka taeva peal või kohal, maa ja taeva vahele võivad ära mahtuda kõik inimese eksistentsiga seotud entiteedid. Eesti murded täiendavad veelgi sellist pilti taevast, millel on mitmekesiseid ruumi ja objekti omadusi (kõrgus, äär, põhi, põrand, lagi, väravad, luugid, võlv, peenar). Nii murretes kui ka 
kirjakeeles võib taevas olla sünonüümne jumalaga, kes tegutseb ja keda appi palutakse. Iseloomulik on, et taevas aktiivse tegutsejana esineb tänapäeva kirjakeeles sagedasti koos mitme eesti keele tuumverbiga, mis esinevad sagedasti ka koos sõnaga jumal (tulema, saama, andma, pidama, võima). Lisaks agendile võib taevas olla lauses ka patsiendi või kogeja rollis, seda eriti ilmastikuga seotud kontekstides (nt koos verbidega selginema, tumenema).

Kokkuvõtteks võib öelda, et sõna taevas analüüs näitas selle sõna väga mitmesuguse mõistmise ja kasutamise võimalusi ning tõi esile fakti, et keel kajastab inimese arusaamist maailmast vastavalt tema vajadusele ennast ümbritsevat mõista (taevas kui eluruum) ning keel näitab ka, kuidas inimene lähedase ja tuttava kaudu kauget ja raskesti määratletavat mõistab.

\author{
Aadress: \\ Ann Veismann, Anni Jürine, Karl Pajusalu, Renate Pajusalu, \\ Ilona Tragel \\ Tartu Ülikool \\ Eesti ja üldkeeleteaduse instituut \\ Jakobi 2, IV korrus \\ 51014 Tartu, Eesti \\ E-post: ann.veismann@ut.ee
}

\title{
Kirjandus
}

EES = Metsmägi, Iris, Meeli Sedrik ja Sven-Erik Soosaar (2012) Eesti etümoloogiasõnaraamat. Tallinn: Eesti Keele Sihtasutus. $<$ http://www.eki.ee/dict/ety/>. Vaadatud 09.02.2017.

EKSS = Langemets, Margit, Mai Tiits, Tiia Valdre, Leidi Veskis, Ülle Viks ja Piret Voll (2009) Eesti keele seletav sõnaraamat. [Eesti kirjakeele seletussõnaraamatu 2., täiendatud ja parandatud trükk.] Tallinn: Eesti Keele Sihtasutus.

$<$ http://www.eki.ee/dict/ekss/>. Vaadatud 09.02.2017.

Evert, Stefan (2005) The statistics of word cooccurrences: word pairs and collocations. Ph.D. Dissertation. Institut für maschinelle Sprachverarbeitung Universität Stuttgart. <http://elib.uni-stuttgart.de/bitstream/11682/2573/1/Evert2005phd.pdf>. Vaadatud 09.02.2017.

Junttila, Santeri (2015) Tiedon kumuloituminen ja trendit lainasanatutkimuksessa. Kantasuomen balttilaislainojen tutkimushistoria. Helsinki: Helsingin Yliopisto.

Jürine, Anni, Karl Pajusalu, Renate Pajusalu, Ilona Tragel, and Ann Veismann (2016)

"Estonian jumal 'god'”. Folklore. Electronic Journal of Folklore 64, 9-32. 


\section{Ann Veismann, Anni Jürine jt}

Kehayov, Petar (2009) "Taboo intensifiers as polarity items: evidence from Estonian". Sprachtypologie und Universalienforschung 62, 140-164.

Klaas, Birute (1996) "Kohakäänete funktsioonidest ja kohakäänete-adpositsioonkonstruktsioonide vastavusest lokaalsuhetes eesti ja leedu keeles". Raili Pool, toim. Emakeel ja teised keeled. II. Tartu, 18.-20. oktoober 1996. Konverentsi ettekanded, 47-54. Tartu: Tartu Ülikooli Kirjastus.

Koivulehto, Jorma (1999) "Varhaiset indoeurooppalaiskontaktit: aika ja paikka lainasanojen valossa". Paul Fogelberg, toim. Pohjan poluilla: Suomalaisten juuret nykytutkimuksen mukaan, 207-236. Helsinki: Societas Scientarum Fennica.

Lakoff, George ja Mark Johnson (2011) Metafoorid, mille järgi me elame. (Tlk E. Vainik) Tallinn: TLÜ Kirjastus.

LELS = Viitso, Tiit-Rein ja Valts Ernštreits (2012) Lìvõkīel-ēstikiel-leţkīel sõnārōntõz. Liivi-eesti-läti sõnaraamat. Lībiešu-igauņu-latviešu vārdnīca. Tartu, Rīga: Tartu Ülikool, Latviešu valodas aǵentūra.

SLW = Winkler, Eberhard ja Karl Pajusalu (2009) Salis-Livisches Wörterbuch. (Linguistica Uralica: Supplementary Series 3.) Tallinn: Estonian Academy Publishers

SSA 1 = Itkonen, Erkki ja Ulla-Maija Kulonen, toim. (1992) Suomen sanojen alkuperä. Etymologinen sanakirja 1. Helsinki: Suomalaisen Kirjallisuuden Seura, Kotimaisten Kielten Tutkimuskeskus.

SSA 3 = Kulonen, Ulla-Maija, toim. (2000) Suomen sanojen alkuperä. Etymologinen sanakirja 3. Helsinki: Suomalaisen Kirjallisuuden Seura, Kotimaisten Kielten Tutkimuskeskus.

Sünonüümisõnastik $=$ Õim, Asta (koost) (1991) Sünonüümisõnastik. Tallinn: Eesti Keele Instituut. http://portaal.eki.ee/dict/synonyymid

Tragel, Ilona (2003) Eesti keele tuumverbid. Doktoritöö. Tartu: Tartu Ülikooli Kirjastus. Uibo, Udo (2014) Sõnalood. Etümoloogilisi vesteid. Tallinn: Tänapäev.

Vainik, Ene (1995) Eesti keele väliskohakäänete semantika kognitiivse grammatika vaatenurgast. Tallinn: Eesti Teaduste Akadeemia Eesti Keele Instituut.

Veismann, Ann (2009) Eesti keele kaas- ja määrsõnade semantika võimalusi. Dissertationes Linguisticae Universitatis Tartuensis 11. Tartu: Tartu Ülikooli Kirjastus.

Velsker, Eva (2010) “Leksikaliseerumine keelemuutuses". Keel ja Kirjandus 7, 521536.

Õim, Asta (2004) “Sõna õhk semantikast”. Emakeele Seltsi aastaraamat 49, 125-135.

\section{Keelekogud}

Eesti Keele Instituudi murdearhiivi sõnavara koondkartoteek

Eesti kirjakeele korpuse tasakaalus korpus: http://www.cl.ut.ee/korpused/grammatikakorpus/index.php?lang=et

Eesti murrete korpus: http://www.murre.ut.ee/

Internetikeele korpus etTenTen:

http://www2.keeleveeb.ee/dict/corpus/ettenten/about.html 


\begin{abstract}
Ann Veismann, Anni Jürine, Karl Pajusalu, Renate Pajusalu and Ilona Tragel: taevas 'sky, heaven' in Estonian. The word taevas in Estonian is considered to be a loan word of Baltic or possibly early Indo-European origin. Taevas has been used to refer to the sky as well as to heaven and heavenly phenomena. This study focuses on the etymology of taevas, and analyses the semantics and collocates of taevas in Estonian dialects and written Estonian. It is demonstrated that, when referring to spatial location, the word taevas may be interpreted as an object, a surface or a container. When taevas is used to refer to heaven, i.e. the location of God in Christianity, the metonymy location for the agent motivates numerous uses where taevas acts as the agent. Such usages are contrasted to usage patterns of Jumal 'God'.
\end{abstract}

Keywords: Standard Estonian, Estonian dialects, the word taevas 'sky, heaven', language history, semantics, polysemy, metonymy 